\title{
NTRK1 Gene Rearrangement
}

National Cancer Institute

\section{Source}

National Cancer Institute. NTRK1 Gene Rearrangement. NCI Thesaurus. Code C46006.

A molecular abnormality indicating rearrangement of the NTRK1 gene. 